\title{
ABNORMALITIES IN NEUROMUSCULAR JUNCTION STRUCTURE AND SKELETAL MUSCLE FUNCTION IN MICE LACKING THE P2X 2 NUCLEOTIDE RECEPTOR
}

\author{
M. RYTEN, ${ }^{a}$ R. KOSHI, ${ }^{b}$ G. E. KNIGHT, ${ }^{a}$ M. TURMAINE, ${ }^{c}$ \\ P. DUNN, ${ }^{a}$ D. A. COCKAYNE, ${ }^{d}$ A. P. W. FORD ${ }^{d}$ \\ AND G. BURNSTOCK ${ }^{\mathrm{a} *}$ \\ ${ }^{a}$ Autonomic Neuroscience Centre, Royal Free and University College \\ Medical School, Rowland Hill Street, London NW3 2PF, UK \\ ${ }^{b}$ Department of Anatomy, Christian Medical College, Vellore, India \\ ${ }^{\circ}$ Department of Anatomy and Developmental Biology, University Col- \\ lege London, London WC1E 6BT, UK \\ ${ }^{d}$ The Neurobiology Unit, Roche Bioscience, Palo Alto, USA
}

\begin{abstract}
ATP is co-released in significant quantities with acetylcholine from motor neurons at skeletal neuromuscular junctions (NMJ). However, the role of this neurotransmitter in muscle function remains unclear. The $\mathrm{P}_{2} \mathrm{X}_{2}$ ion channel receptor subunit is expressed during development of the skeletal NMJ, but not in adult muscle fibers, although it is reexpressed during muscle fiber regeneration. Using mice deficient for the $\mathrm{P} 2 \mathrm{X}_{2}$ receptor subunit for ATP $\left(\mathrm{P}_{2} \mathrm{X}_{2}{ }^{-l}\right)$, we demonstrate a role for purinergic signaling in NMJ development. Whereas control NMJs were characterized by precise apposition of pre-synaptic motor nerve terminals and postsynaptic junctional folds rich in acetylcholine receptors (AChRs), NMJs in $\mathrm{P}_{2} \mathrm{X}_{2}{ }^{-1-}$ mice were disorganized: misapposition of nerve terminals and post-synaptic AChR expression localization was common; the density of post-synaptic junctional folds was reduced; and there was increased end-plate fragmentation. These changes in NMJ structure were associated with muscle fiber atrophy. In addition there was an increase in the proportion of fast type muscle fibers. These findings demonstrate a role for $\mathrm{P} 2 \mathrm{X}_{2}$ receptor-mediated signaling in NMJ formation and suggest that purinergic signaling may play an as yet largely unrecognized part in synapse formation. (C) 2007 IBRO. Published by Elsevier Ltd. All rights reserved.
\end{abstract}

Key words: ATP, acetylcholine, knockout, mouse, nerve terminal, synapse.

It is well established that ATP is co-released with acetylcholine (ACh) from motor nerve terminals (Redman and Silinsky, 1994; Redman and Silinsky, 1996). While ACh is the transmitter that mediates via nicotinic receptors muscle contraction in mature animals, during early development both ATP, acting via P2X ion channel receptors (Ralevic and Burnstock, 1998) and ACh mediate muscle responses

*Corresponding author. Tel: +44-0-20-7830-2948; fax: +44-0-207830-2949.

E-mail address: g.burnstock@ucl.ac.uk (G. Burnstock).

Abbreviations: ACh, acetylcholine; AChR, acetylcholine receptor; $E$, embryonic day; NMJ, neuromuscular junction; $P$, postnatal day; PBS, phosphate-buffered saline; $\mathrm{P}_{2} \mathrm{X}_{2}{ }^{-1-}, \mathrm{P}_{2} \mathrm{X}_{2}$ receptor knockout mouse.
(Kolb and Wakelam, 1983; Henning, 1997; Heilbronn and Eriksson, 1998). $\mathrm{P} 2 \mathrm{X}_{2}$ receptor subunits are expressed during early postnatal development, when neuromuscular junction (NMJ) maturation and patterning occur, but disappear in the adult (Ryten et al., 2001). Furthermore, this receptor is re-expressed in the later stages of muscle regeneration in the mdx mouse model of muscular dystrophy (Ryten et al., 2004; Jiang et al., 2005). Also direct postjunctional responses to ATP reappear after denervation of chick skeletal muscle (Wells et al., 1995).

Electrophysiology, immunohistochemistry and reverse transcriptase polymerase chain reaction have demonstrated the expression of a range of purinoceptors in developing skeletal muscle, including $\mathrm{P} 2 \mathrm{X}_{2}, \mathrm{P} 2 \mathrm{X}_{5}, \mathrm{P} 2 \mathrm{X}_{6}$, $\mathrm{P} 2 \mathrm{Y}_{1}, \mathrm{P} 2 \mathrm{Y}_{2}$ and $\mathrm{P} 2 \mathrm{Y}_{4}$ (Kolb and Wakelam, 1983; Hume and Thomas, 1988; Thomas et al., 1991; Henning et al., 1992; Meyer et al., 1999a,b; Bo et al., 2000; Ruppelt et al., 2001; Ryten et al., 2001; Cheung et al., 2003). Specific roles in skeletal muscle fiber formation and function have been identified for two of these receptors. While activation of the P2Y receptor has been shown to regulate acetylcholine receptor (AChR) and acetylcholinesterase (AChE) expression at NMJs (Choi et al., 2001; Ling et al., 2004), the $\mathrm{P} 2 \mathrm{X}_{5}$ receptor has been implicated in the regulation of myoblast activity and muscle regeneration (Ryten et al., $2002,2004)$. The function of the $\mathrm{P} 2 \mathrm{X}_{2}$ receptor is less clear. However, the singular ability of this receptor type to interact with nicotinic AChRs to produce cross-inhibition of channel opening (Nakazawa, 1994; Barajas-López et al., 1998; Searl et al., 1998; Zhou and Galligan, 1998; Khakh et al., 2000), and the timing of $\mathrm{P}_{2} \mathrm{X}_{2}$ receptor expression in development suggests a role for purinergic signaling in the late stages of NMJ formation and patterning.

In the present study we use the $\mathrm{P} 2 \mathrm{X}_{2}$ receptor knockout mouse $\left(\mathrm{P}_{2} \mathrm{X}_{2}{ }^{-l-}\right)$ (Cockayne et al., 2005) to investigate the role of the $\mathrm{P} 2 \mathrm{X}_{2}$ receptor in NMJ development and skeletal muscle function.

\section{EXPERIMENTAL PROCEDURES}

\section{Animals}

$\mathrm{P} 2 \mathrm{X}_{2}{ }^{-1-}$ mice were generated by introducing a deletion encompassing exons $2-11$ into the mouse $\mathrm{P} 2 \mathrm{X}_{2}$ gene (see Cockayne et al., 2005 for details).

\section{Immunohistochemistry and histology}

Four female wild-type and four $\mathrm{P}_{2} \mathrm{X}_{2}{ }^{-1-}$ mice were killed by $\mathrm{CO}_{2}$ asphyxiation and death was confirmed by cervical dislocation according to Home Office (UK) regulations covering Schedule 1 
procedures. All experiments conformed to the Royal Free and University College Medical School guidelines on the ethical use of animals; experiments were designed to minimize the use and suffering of animals. The soleus muscles were rapidly removed. Muscle samples used for the assessment of muscle fiber number, muscle fiber size or muscle fiber type were cut such that the mid-belly region was isolated, covered with OCT compound and frozen in liquid nitrogen-cooled isopentane. Cryostat sections $(12 \mu \mathrm{m})$ were cut to produce transverse muscle sections. Sections showing the largest muscle bulk were collected on gelatinized slides, stained with Toluidine Blue and used for assessment of muscle fiber number and size. For assessment of muscle fiber type by demonstration of myofibrillar ATPase we followed the method described by Dubowitz (1985) with preincubation of fresh frozen muscle sections in alkali buffer (pH 9.4). In order to immunostain for fast skeletal muscle myosin, cryostat sections were fixed in $4 \%$ formaldehyde in $0.1 \mathrm{M}$ phosphate buffer for $2 \mathrm{~min}$, rinsed several times in phosphate-buffered saline (PBS) and incubated overnight with a monoclonal antibody (diluted $1: 100$ in 10\% goat serum in PBS) that exclusively recognizes fast skeletal muscle myosin (Sigma Chemical Co., Poole, UK). Immunoreactivity was visualized by incubation with goat antimouse fluorescein-conjugated secondary antibody (Stratech Scientific, Newmarket, UK). Muscle samples used for visualization of NMJs were pinned at proximal and distal ends to sylgard and fixed in $4 \%$ paraformaldehyde in PBS for 45 min, rinsed briefly and sunk in $20 \%$ sucrose in PBS. Following fixation, muscle fibers were teased apart using fine forceps and incubated with Texas Red-labeled $\alpha$-bungarotoxin (Invitrogen Ltd., Paisley, UK) diluted 1:1000 in PBS. To immunostain for synaptophysin, teased muscle fibers were incubated overnight in rabbit anti-synaptophysin antibodies (Synaptic Systems, Goettingen, Germany) diluted 1:100 in 10\% goat serum in PBS. Immunoreactivity was visualized using goat anti-rabbit fluorescein-conjugated secondary antibody (Stratech Scientific). Images were captured using a Leica (Heerbrugg, Switzerland) confocal microscope and the sum pixel function Leica analysis software to collapse z-series stacks taken through entire NMJs.

\section{Analysis of AChR expression at NMJs}

Teased muscle fibers stained with Texas Red-labeled $\alpha$-bungarotoxin and photographed as described above, were used for analysis of AChR expression at NMJs. Using Scion Image analysis software (NIH, USA) the number of AChR clusters per NMJ and total area of $\mathrm{AChR}$ expression per NMJ were measured. A minimum of 45 NMJs (taken from at least three mice) were sampled to make up each experimental group. End-plate morphology (cluster number) in wild-type and $\mathrm{P}_{2} \mathrm{X}_{2}{ }^{-1-}$ soleus muscles were compared using the Mann-Whitney test since the data were clearly not normally distributed. The total area of AChR expression per $\mathrm{NMJ}$ in wild-type and $\mathrm{P}_{2} \mathrm{X}_{2}{ }^{-1-}$ soleus muscles was compared using a two-tailed unpaired Student's $t$-test. A probability level of $P<0.05$ was taken as significant in all tests.

\section{Measurement of muscle fiber number}

A minimum of five samples, each taken from different mice $(n=4)$, was used to assess muscle fiber number in wild-type or $\mathrm{P} 2 \mathrm{X}_{2}{ }^{-1-}$ soleus muscles. Soleus muscle sections prepared as described above were used for analysis and photographed under $\times 2.5$ magnification using a Nikon digital camera. Muscle fiber numbers were counted by enlarging the screen image and using a grid (to prevent accidental re-counting of fibers). Wild-type and $\mathrm{P} 2 \mathrm{X}_{2}{ }^{-1-}$ soleus muscle fiber numbers were compared using an unpaired Student's $t$-test. The numbers of fast (type II) muscle fibers, as demonstrated by myofibrillar ATPase were measured in a similar manner and expressed as a $\%$ of the total number of muscle fibers counted. The percentage of fast type muscle fibers in wild-type and $\mathrm{P} 2 \mathrm{X}_{2}{ }^{-1-}$ soleus muscle was compared using an unpaired Student's $t$-test.

\section{Assessment of the incidence of centrally nucleated fibers}

A minimum of four samples from different mice $(n=4)$ was used to assess the incidence of centrally nucleated fibers in wild-type or $\mathrm{P} 2 \mathrm{X}_{2}{ }^{-1-}$ soleus muscles. Using the method described above, the total number and the number of centrally nucleated muscle fibers were counted. The incidence of centrally nucleated muscle fibers (expressed as a percentage of the total number of muscle fibers) in wild-type and $\mathrm{P} 2 \mathrm{X}_{2}{ }^{-1-}$ muscle was compared using an unpaired Student's $t$-test.

\section{Measurement of muscle fiber cross-sectional area}

A minimum of five different samples, each taken from different mice, was used to assess muscle fiber cross-sectional area in wild-type or $\mathrm{P} 2 \mathrm{X}_{2}{ }^{-1-}$ soleus muscles. Soleus muscle sections prepared as described above were used for analysis, and photographed under $\times 20$ magnification using a Nikon digital camera. Two sections per muscle were analyzed. Images were viewed on a computer screen and a $200 \mu \mathrm{m} \times 200 \mu \mathrm{m}$ grid was applied to each image. Random selection of muscle fibers was achieved by making fiber area measurements only on fibers overlying points of grid intersections. Cross-sectional fiber area was measured using Scion Image analysis software and expressed in $\mu \mathrm{m}^{2}$. In this way at least 70 muscle fibers (approximately $8 \%$ of muscle fibers) were sampled from each image and a total of 702 wild-type and 719 $\mathrm{P} 2 \mathrm{X}_{2}{ }^{-1-}$ soleus muscle fibers were measured. Average crosssectional fiber areas (calculated for each muscle sample) from wild-type $(n=5)$ and $\mathrm{P}_{2} \mathrm{X}_{2}^{-1-}(n=5)$ soleus muscles were compared using a two-tailed unpaired Student's $t$-test.

\section{Electron microscopy}

Soleus muscles from three wild-type and three $\mathrm{P} 2 \mathrm{X}_{2}{ }^{-1-}$ animals were fixed in $2 \%$ glutaraldehyde in $0.1 \mathrm{M}$ cacodylate buffer, washed, post-fixed in $1 \%$ osmium tetroxide $\left(\mathrm{OsO}_{4}\right)$, dehydrated in graded alcohol and embedded in resin. Thin longitudinal sections were cut at $80 \mathrm{~nm}$ thick, stained with uranyl acetate and lead citrate and examined under a JEM-1010 electron microscope. To quantify fold density, the total length of terminal contact was measured on photomicrographs and the number of junctional folds that could be seen was recorded. Measurements from wildtype and $\mathrm{P} 2 \mathrm{X}_{2}^{-1-}$ muscles were compared using a two-tailed unpaired Student's $t$-test.

\section{Physiology}

The soleus muscle from five wild-type and five $\mathrm{P} 2 \mathrm{X}_{2}{ }^{-1-}$ mice was dissected free and placed in continually gassed $\left(95 \% \mathrm{O}_{2} / 5 \% \mathrm{CO}_{2}\right)$ modified Krebs solution (mM): $\mathrm{NaCl}, 133 ; \mathrm{KCl}, 4.7 ; \mathrm{NaHCO}_{3}, 16.4$; $\mathrm{MgSO}_{4}, 0.6 ; \mathrm{NaH}_{2} \mathrm{PO}_{4}, 1.4$; glucose, 7.7 ; and $\mathrm{CaCl}_{2}, 2.5 ; \mathrm{pH} 7.3$ at $37 \pm 1{ }^{\circ} \mathrm{C}$. One end of the muscle was attached to a rigid support and the other to a Grass FT03C force displacement transducer via silk ligatures and mounted in $10 \mathrm{ml}$ organ baths. Mechanical activity was recorded using PowerLab Chart for Windows (Version 4; ADInstruments New South Wales, Australia). An initial load of $1 \mathrm{~g}$ was applied to each soleus muscle, which was allowed to equilibrate for $60 \mathrm{~min}$. Contractions were elicited by electrical stimulation of the muscle via two platinum wire rings $2.5 \mathrm{~mm}$ in diameter and $1 \mathrm{~cm}$ apart through which the soleus muscles were threaded.

\section{Nerve-mediated and muscle-mediated twitch responses}

Twitch contractile responses due to the stimulation of nerves were achieved by using: $100 \mathrm{~V}, 0.1 \mathrm{~ms}$ duration and one twitch/min. By extending the duration of stimulation to $5 \mathrm{~ms}$ direct stimulation of 
muscle was achieved. In each case the means of five responses per soleus muscle were taken and a mean contraction (in g) was calculated for each muscle (from a total of five animals per group). Muscle-mediated tetanic contractions were measured in both wildtype and $\mathrm{P} 2 \mathrm{X}_{2}{ }^{-1-}$ soleus muscles by stimulating with $100 \mathrm{~V}, 5 \mathrm{~ms}$ duration at $50 \mathrm{~Hz}$, until a maximum contraction was achieved. All contractions were compared using a two-tailed unpaired Student's $t$-test.

\section{Tubocurarine sensitivity}

The inhibitory effect of tubocurarine $(0.1-3 \mathrm{mM})$ against nervemediated twitch responses was compared in wild-type and $\mathrm{P} 2 \mathrm{X}_{2}{ }^{-1-}$ soleus muscles. The effect of tubocurarine on muscleinduced twitches was calculated as mean \% reduction of force \pm S.E.M. ( $n$ animals) and a concentration-response curve constructed for wild-type and $\mathrm{P}_{2} \mathrm{X}_{2}{ }^{-1-}$ soleus muscles. The curves were compared using a two-way analysis of variance (ANOVA) followed by a Bonferroni's post hoc test.

\section{Single channel recording from muscle fiber end-plates}

The foot muscles (lumbrical and flexor digitorum brevis) were removed from at least six animals per group and incubated in extracellular solution containing collagenase (Worthington CLS2, $2 \mathrm{mg} \mathrm{ml}^{-1}$ ) for $1 \mathrm{~h}$ at $37^{\circ} \mathrm{C}$. The muscles were then rinsed thoroughly in enzyme free solution and triturated gently to release single muscle fibers. The fibers were allowed to adhere to the bottom of $35 \mathrm{~mm}$ diameter culture dishes (Falcon), and viewed using an inverted microscope with a $40 \times$ phase contrast objective. Single channel recording in the cell attached or inside out configuration was carried out at room temperature $\left(21-23^{\circ} \mathrm{C}\right)$, using an Axopatch 1B (Axon Instruments, Union City, CA, USA). Data were filtered at $5 \mathrm{kHz}$, digitized at $10 \mathrm{kHz}$ and stored on a personal computer using pClamp v8, for offline analysis using Fetchan v6. Electrodes were pulled from thick wall borosilicate glass and had a resistance of 8-12 $M \Omega$ when filled with bathing solution containing $1 \mu \mathrm{M} \mathrm{ACh}$. The bathing solution consisted of $(\mathrm{mM}): \mathrm{NaCl} 154 ; \mathrm{KCl} 4.7 ; \mathrm{MgCl}_{2}$ 1.2; $\mathrm{CaCl}_{2} 2.5 ; \mathrm{HEPES} 10$ and glucose 5.6; the $\mathrm{pH}$ was adjusted to 7.4 using $\mathrm{NaOH}$. The slope conductance of the single channels was determined from linear regression of single channel current amplitude, recorded during ramp changes in membrane potential, versus patch membrane potential.

\section{RESULTS}

$\mathrm{P} 2 \mathrm{X}_{2}{ }^{-1-}$ mice were fertile with no signs of gross pathology. We did not detect any significant differences in body mass (27.8 g $\pm 1.7 \mathrm{~g}$, wild-type; $27.6 \mathrm{~g} \pm 0.5 \mathrm{~g}, \mathrm{P}_{2} \mathrm{X}_{2}{ }^{-1}$ mice). While differences in the muscle masses of wild-type and $\mathrm{P} 2 \mathrm{X}_{2}{ }^{-1-}$ extensor digitorum longus $(10.9 \pm 0.7 \mathrm{mg}$, wildtype; $9.68 \pm 0.5 \mathrm{mg}, \mathrm{P}_{2} \mathrm{X}_{2}{ }^{-1-}$ ) and soleus muscles $\left(9.1 \pm 0.44 \mathrm{mg}\right.$, wild-type; $8.2 \pm 0.32 \mathrm{mg}, \mathrm{P}_{2} \mathrm{X}_{2}{ }^{-1-}$ ) were suggestive of muscle atrophy, values did not reach significance ( $P=0.15$ for soleus muscle).

\section{$\mathrm{P} 2 \mathrm{X}_{2}$ receptor expression in developing skeletal muscle}

Using immunohistochemistry we confirmed the expression of $\mathrm{P} 2 \mathrm{X}_{2}$ receptor protein in developing wild-type skeletal muscle (Fig. 1a). Immunostaining for the $\mathrm{P} 2 \mathrm{X}_{2}$ receptor was not observed in embryonic day 14 (E14) skeletal a
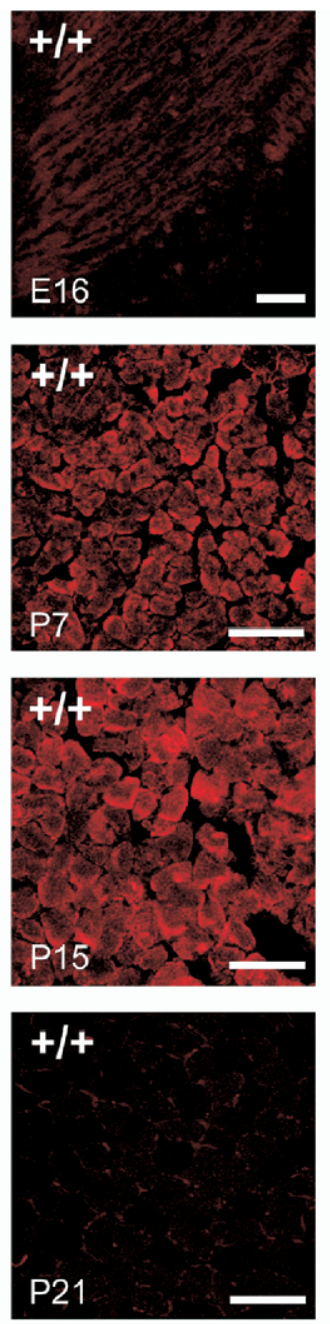

C

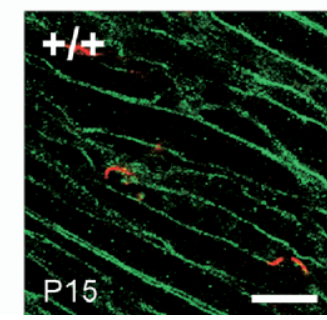

b
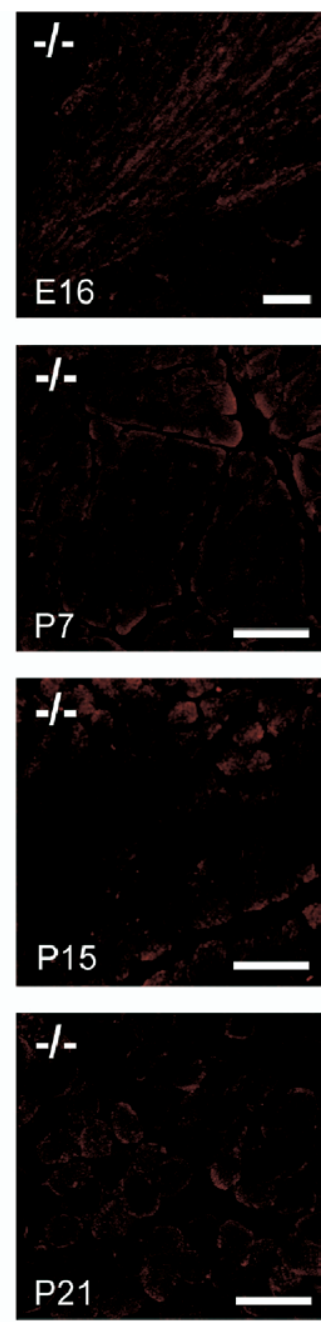

d

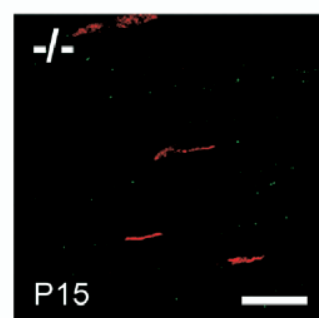

Fig. 1. $P 2 X_{2}$ receptor expression in developing $P 2 X_{2}{ }^{-1-}$ and wild-type skeletal muscle. (a) Immunostaining of wild-type control E16 lower limb muscles, P7, P15 and P21 soleus muscle. Expression of the P2X receptor was found on wild-type skeletal muscle at P7 and P15 only. This expression was localized to muscle fiber membranes with no receptor expression in between muscle fibers at any stage. (b) There was no evidence of $\mathrm{P} 2 \mathrm{X}_{2}$ receptor expression in skeletal muscle at any stage of development (E16, P7, P15 and P21). Scale bars $=50 \mu \mathrm{m}$. (c) Double-staining for $\mathrm{AChRs}$ (red) and $\mathrm{P} 2 \mathrm{X}_{2}$ receptors (green) in wild-type soleus muscle at P15. (d) Double-staining for AChRs (red) and $\mathrm{P} 2 \mathrm{X}_{2}$ receptors (green) in wild-type soleus muscle at P15. Scale bars $=50 \mu \mathrm{m}$. Wild-type, $(+/+) ; \mathrm{P}_{2} \mathrm{X}_{2}^{-l-},(-/-)$.

muscle, this receptor was strongly expressed in wild-type postnatal day 3 (P3), P7 and P15 muscle (Fig. 1a). Immunostaining was localized to the muscle fiber membranes and spread along the length of the muscle fibers. There was no evidence of specific localization of $\mathrm{P}_{2} \mathrm{X}_{2}$ receptor 
expression at NMJs as shown by double-staining P15 soleus muscle for both the $\mathrm{P}_{2} \mathrm{X}_{2}$ receptor and AChRs (Fig. 1c). $P 2 X_{2}$ receptor expression was not maintained in $P 21$ or in adult wild-type skeletal muscle (Fig. 1a). This pattern of $\mathrm{P}_{2} \mathrm{X}_{2}$ receptor expression is not consistent with specific receptor expression at NMJs or in motor nerve bundles between muscle fibers. There was no evidence of $\mathrm{P} 2 \mathrm{X}_{2}$ receptor expression at any age in $\mathrm{P}_{2} \mathrm{X}_{2}{ }^{-1-}$ skeletal muscle (Fig. 1b and d).

\section{Abnormalities in NMJ structure in $\mathrm{P}_{2} \mathrm{X}_{2}^{-l-}$ skeletal muscle visualized by light microscopy}

In wild-type soleus muscle we observed the previously described transformation of endplates from simple oval plaques of AChRs at high density, to perforated plaques, and ultimately to continuous pretzel-shaped areas of AChR expression (Fig. 2a).

There appeared to be no differences in endplate morphology between wild-type and $\mathrm{P} 2 \mathrm{X}_{2}{ }^{-1-}$ skeletal muscle at $\mathrm{P} 7$. However, $\mathrm{P} 2 \mathrm{X}_{2}{ }^{-1-}$ endplates examined at later stages of development (P15 and adult) were less organized than age-matched controls. In particular, the smooth outline of the endplate regions observed in wild-type muscle fibers at P15 (representing the demarcation between high and low AChR expression) appeared blurred in endplates from $\mathrm{P}_{2} \mathrm{X}_{2}{ }^{-1-}$ muscle fibers (Fig. 2a). Abnormalities in NMJ morphology in $\mathrm{P}_{2} \mathrm{X}_{2}{ }^{-1-}$ muscle became more prominent with increasing age (P15 and adult). Unlike the endplates in adult wild-type soleus muscle, which consisted of continuous pretzel-shaped areas of AChR expression, many endplates in adult $\mathrm{P}_{2} \mathrm{X}_{2}{ }^{-1-}$ soleus muscle were fragmented with multiple separate clusters of AChRs (Fig. 2a). Quantitative analysis of endplate structure confirmed this impression, demonstrating a significant increase in the number of AChR clusters/endplate in $\mathrm{P}_{2} \mathrm{X}_{2}{ }^{-1-}$ as compared with wild-type soleus muscle $(P=0.00081)$ (Fig. $2 b)$. Endplates in $\mathrm{P}_{2} \mathrm{X}_{2}{ }^{-1-}$ muscle $(54.9 \pm 2.0 \mu \mathrm{m})$ were also significantly longer than those in age-matched wild-type $(49.3 \pm 1.6 \mu \mathrm{m})$ soleus muscle $(P=0.031)$. Despite these differences in endplate morphology, there was no significant difference in the total area of AChR expression per endplate in wild-type $\left(527 \pm 27 \mu \mathrm{m}^{2}\right)$ as compared with $\mathrm{P}_{2} \mathrm{X}_{2}{ }^{-1-}\left(561 \pm 23 \mu \mathrm{m}^{2}\right)$ soleus muscle (Fig. 2c). Similarly we found no significant difference in the intensity of fluorescence (visualized by Texas Red-labeled $\alpha$-bungarotoxin binding) at wild-type (173.2 \pm 1.8 units) and $\mathrm{P}_{2} \mathrm{X}_{2}{ }^{-1-}$ (176.9 \pm 4.4 units) NMJs.

Adult skeletal muscle fibers were also double-stained with anti-synaptophysin to visualize nerve terminals and Texas Red-labeled bungarotoxin to visualize post-synaptic AChRs. In wild-type soleus muscle NMJs were characterized by apposition of nerve terminal branches and AChR-rich segments of post-synaptic membrane, visualized as yellow staining (Fig. 2d). However, in some $\mathrm{P}_{2} \mathrm{X}_{2}{ }^{-1-}$ NMJs there was misalignment between the AChR-rich regions of the post-synaptic membrane (red) and nerve terminal branches (green) (Fig. 2d). Analysis of en face images of NMJs demonstrated significantly less $(P=0.013)$ alignment of synaptophysin and AChR expression (as visualized by yellow staining) in $\mathrm{P}_{2} \mathrm{X}_{2}^{-1-}$ (68.8 $\pm 3.2 \%$ of total AChR expression) as compared with wild-type NMJs $(81.0 \pm 3.1 \%$ of total AChR expression).

\section{Abnormalities in the ultrastructure of NMJs in $\mathrm{P}_{2} \mathrm{X}_{2}^{-l-}$ soleus muscle}

In wild-type soleus muscles, NMJs (at all ages) were characterized by the presence of nerve terminals capped by Schwann cell processes and post-synaptic muscle specialization, including junctional folds, a raised myofilamentpoor sole plate and aggregates of myonuclei (Fig. 3). Although junctional folds were also observed in $\mathrm{P}_{2} \mathrm{X}_{2}{ }^{-1-}$ NMJs examined at $P 15$, there was a reduction in the density and depth of folds in the $\mathrm{P} 2 \mathrm{X}_{2}{ }^{-1-}$ muscles (Fig. $3 a)$. This difference in fold accumulation or maintenance persisted and became more prominent in adult muscle (Fig. 3b). There were $5.2 \pm 0.2$ junctional folds $/ \mu \mathrm{m}$ in wildtype adult NMJs, but only $3.4 \pm 0.2$ junctional folds $/ \mu \mathrm{m}$ in $\mathrm{P}_{2} \mathrm{X}_{2}{ }^{-1-}$ NMJs (Fig. 3c). In areas of infolding of the postjunctional membrane, the folds appeared to be shallower than those in wild-type NMJs (Fig. 3a and b). Most surprising was the apparent variability in post-junctional differentiation within some NMJs. Whereas the majority of the post-junctional membrane apposing the nerve terminal in Fig. 3b appears flat (with no junctional folds), a small portion is extensively folded.

\section{Channel properties of AChRs expressed in $\mathrm{P}_{2} \mathrm{X}_{2}$ receptor positive wild-type and $\mathrm{P} 2 \mathrm{X}_{2}{ }^{-1-}$ muscle fibers}

The properties of the specific AChR subtypes (embryonic, $\gamma$ subunit-containing or adult, $\varepsilon$ subunit-containing AChRs) expressed at the endplate are known to influence NMJ maturation (Missias et al., 1997). Therefore we investigated the channel properties of the AChRs expressed at wild-type and $\mathrm{P}_{2} \mathrm{X}_{2}{ }^{-1-}$ skeletal muscle. Single channel properties of digitorum brevis end-plates in P5 wild-type muscle fibers had the characteristics of typical embryonic channels, with longer openings and a lower conductance (Fig. 4a, Table 1). In contrast, adult wild-type mice revealed $A C h R$ channels with typical adult characteristics, including short opening times and a high conductance (Fig. $4 a$, Table 1). The mean open time and conductance for channels from adult digitorum brevis $\mathrm{P}_{2} \mathrm{X}_{2}{ }^{-1-}$ endplates were similar to those from adult wild-type muscle. The presence of adult-type AChRs in both wild-type and P $2 \mathrm{X}_{2}{ }^{-1-}$ tissue was confirmed by the absence of significant immunostaining for the $\gamma$ (embryonic) AChR subunit (Fig. 4b).

\section{Muscle fiber atrophy in soleus muscle from $\mathrm{P}_{2} \mathrm{X}_{2}^{-1-}$ mice}

Examination of $\mathrm{P} 2 \mathrm{X}_{2}{ }^{-1-}$ soleus muscle sections did not reveal evidence of muscle necrosis (excessive connective tissue) or regeneration (central nuclei) at any age (E14, P4, P7, P14, P21 and adult). This was confirmed by mea- 

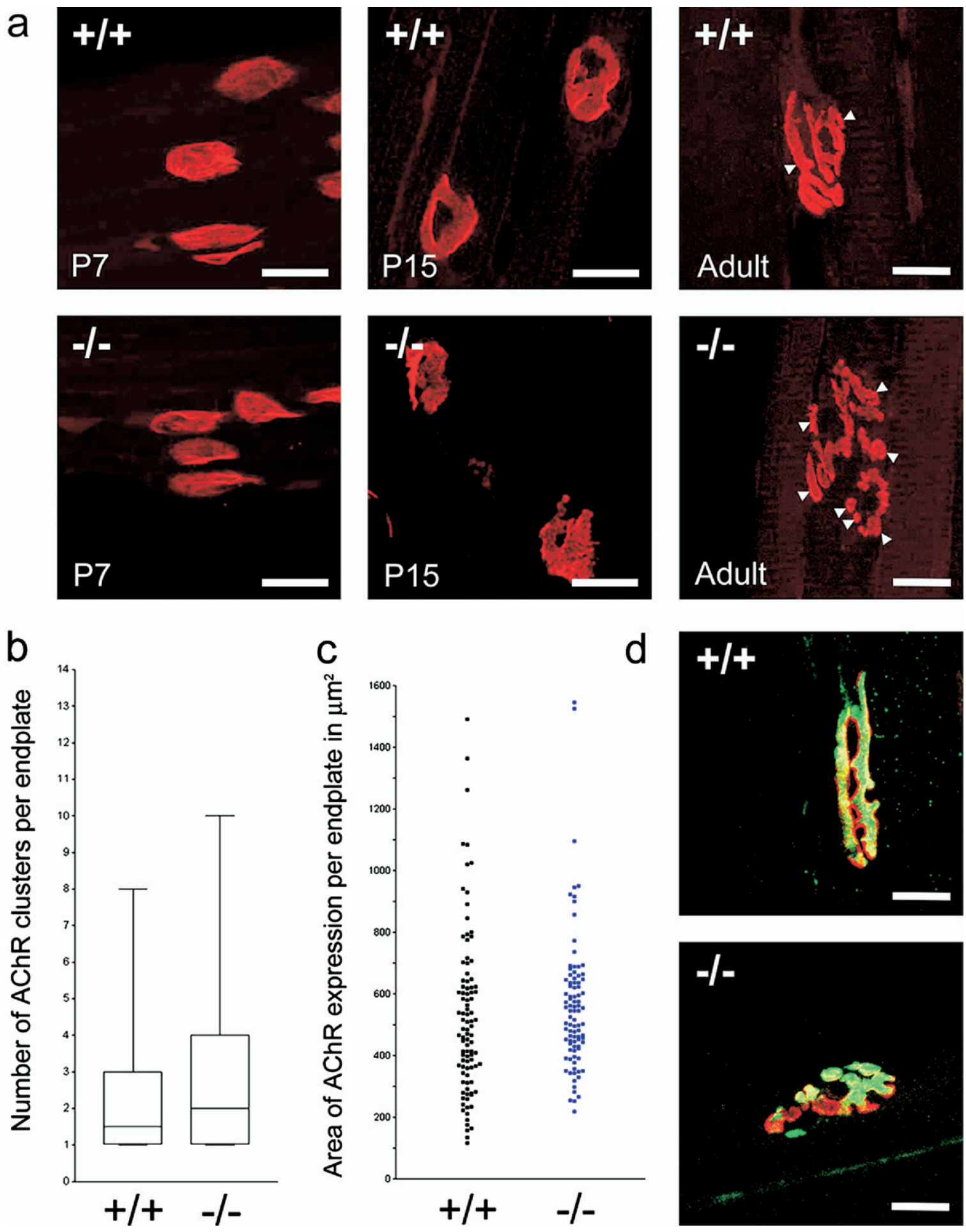

Fig. 2. Abnormalities in NMJ structure in $\mathrm{P}_{2} \mathrm{X}_{2}{ }^{-1-}$ skeletal muscle visualized by confocal microscopy. (a) Representative endplates stained with Texas Red-labeled $\alpha$-bungarotoxin for AChRs from P7, P15 and adult wild-type and P2 $\mathrm{X}_{2}{ }^{-1-}$ soleus muscles. Whereas at P7 endplates in control and $\mathrm{P} 2 \mathrm{X}_{2}{ }^{-1-}$ skeletal muscle were indistinguishable, by P15 some endplates in $\mathrm{P}_{2} \mathrm{X}_{2}{ }^{-1-}$ skeletal muscle appeared ragged. Furthermore, while control adult endplates consisted of a single AChR cluster per endplate (white arrowheads), in $\mathrm{P}_{2} \mathrm{X}_{2}^{-1-}$ muscle the number of clusters per endplate was significantly greater. Scale bars $=20 \mu \mathrm{m}$. (b) Box and whisker diagram to show the number of clusters of AChR expression per adult endplate. (c) Scatter plot to show the maximum distance between areas of $\mathrm{AChR}$ expression within a single adult endplate in wild-type and $\mathrm{P} 2 \mathrm{X}_{2}{ }^{-1-}$ soleus muscle. No significant difference in the total area of $\mathrm{AChR}$ expression in wild-type and $\mathrm{P} 2 \mathrm{X}_{2}{ }^{-1-}$ was found, suggesting that the total number of $\mathrm{AChRs}$ expressed was similar. (d) Representative NMJs from adult wild-type and $\mathrm{P} 2 \mathrm{X}_{2}{ }^{-1-}$ soleus muscles double-stained for the nerve terminal protein, synaptophysin (green) and AChRs (red). Precise apposition of nerve terminals and AChR-rich regions of the post-synaptic membrane (as visualized by yellow staining) was a feature of control adult NMJs. However, in $\mathrm{P} 2 \mathrm{X}_{2}{ }^{-1-}$ muscle there were areas of $\mathrm{AChR}$ expression on muscle without overlying nerve fibers (red staining only) and nerve terminals that were not apposed by AChR-rich muscle regions (green staining only). Scale bars $=20 \mu \mathrm{m}$. Wild-type $(+/+), \mathrm{P}^{2} \mathrm{X}_{2}^{-I-}(-I-)$. 
a
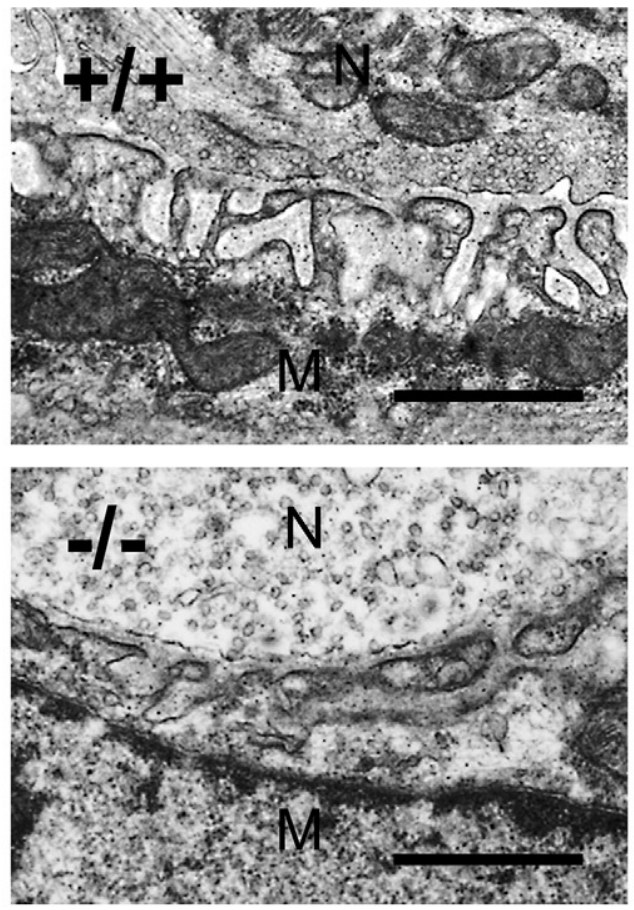

C

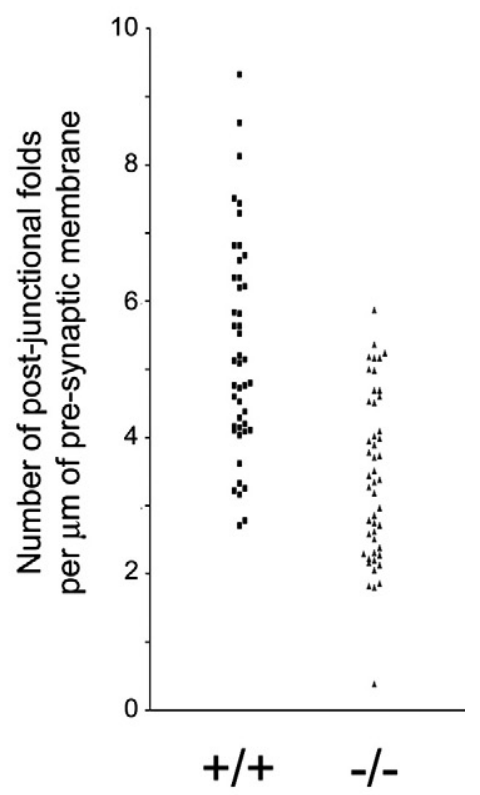

b
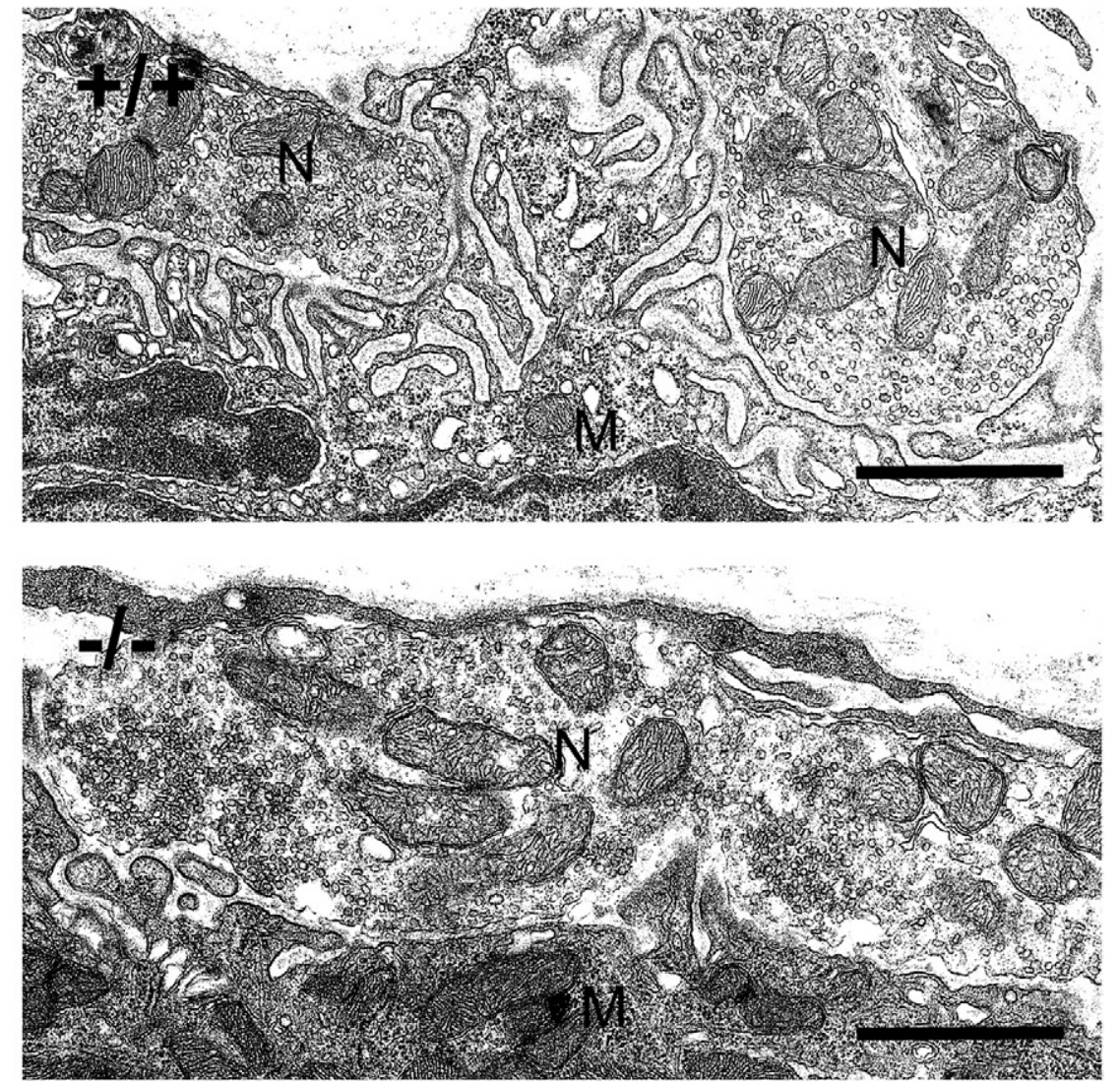

Fig. 3. Abnormalities in the ultrastructure of NMJs in $\mathrm{P} 2 \mathrm{X}_{2}$ receptor-deficient soleus muscle. (a) Electron micrographs of representative NMJs in wild-type and $\mathrm{P} 2 \mathrm{X}_{2}{ }^{-1-}$ soleus muscles at P15 demonstrating the development of deep postsynaptic folds. Whereas wild-type NMJs developed deep post-synaptic folds, post-synaptic folds in $\mathrm{P} 2 \mathrm{X}_{2}{ }^{-1-}$ soleus muscle at $\mathrm{P} 15$ were shallow and fewer in number. Scale bar $=1 \mu \mathrm{m}$. (b) Electron micrographs of representative NMJs in adult wild-type and $\mathrm{P}_{2} \mathrm{X}_{2}{ }^{-1-}$ soleus muscle. At wild-type NMJs the post-synaptic membrane of the muscle fiber (M) underlying the motor nerve terminal (N) was extensively folded. NMJs in $\mathrm{P}_{2} \mathrm{X}_{2}^{-1-}$ soleus muscle were characterized by reduced folding of the post-synaptic membrane of the muscle (M) underlying nerve terminals (N). Scale bar $=1 \mu \mathrm{m}$. (c) Scatter plot to show the density of post-synaptic folds at NMJs in wild-type and P2X ${ }_{2}^{-1-}$ adult soleus muscle. Wild-type $(+/+)$, $\mathrm{P} 2 \mathrm{X}_{2}^{-1-}(-1-)$. 

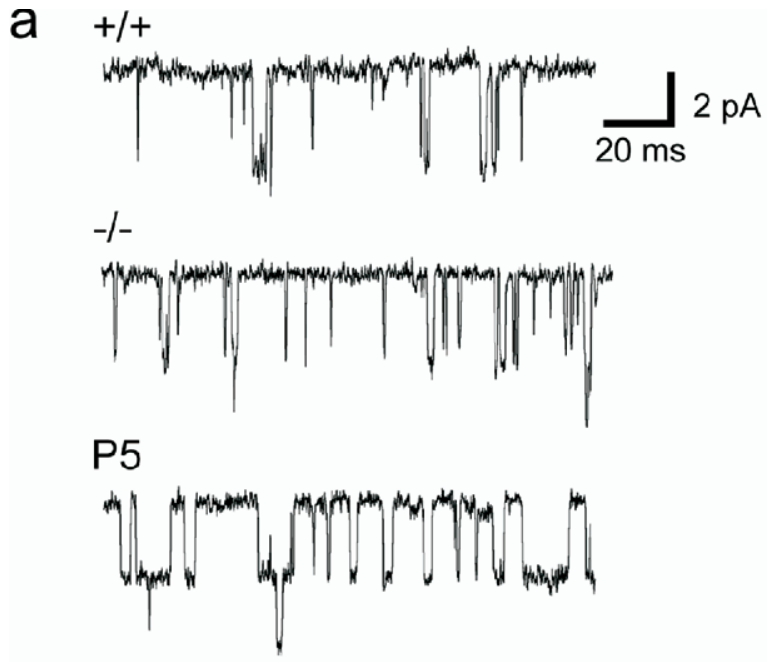

b
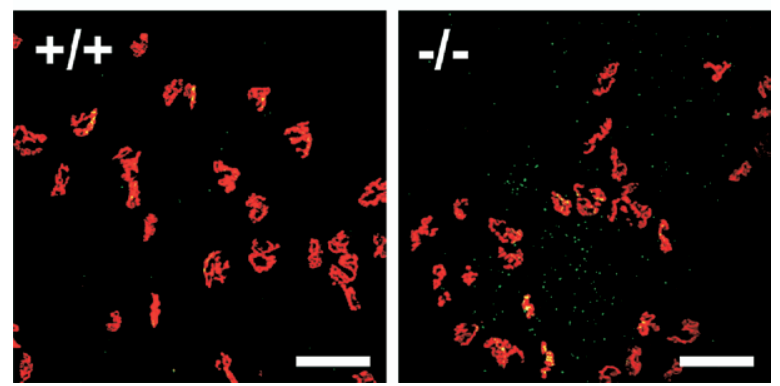

Fig. 4. Properties of AChRs expressed in wild-type and $\mathrm{P} 2 \mathrm{X}_{2}{ }^{-1-}$ muscle fibers could be detected. (a) Single channel recordings from adult wild-type, adult $\mathrm{P} 2 \mathrm{X}_{2}{ }^{-1-}$ and $\mathrm{P} 5$ mouse digitorum brevis muscle endplates in the presence of $1 \mu \mathrm{M} \mathrm{ACh}$. (b) Embryonic-type $\gamma \mathrm{AChR}$ subunits were not expressed in wild-type or $\mathrm{P}_{2} \mathrm{X}_{2}{ }^{-1-}$ soleus muscle. Representative NMJs from adult wild-type and $\mathrm{P} 2 \mathrm{X}_{2}{ }^{-1-}$ digitorum brevis muscle double-stained for AChRs with Texas Red-labeled $\alpha$-bungarotoxin (red) and a specific antibody against the $\gamma$ subunit of the AChR (green). The absence of green and yellow staining demonstrates that the AChRs expressed in both wild-type and $\mathrm{P} 2 \mathrm{X}_{2}{ }^{-1-}$ digitorum brevis muscle did not contain the $\gamma$ subunit, suggesting the presence of mature as opposed to embryonic-type AChRs. Scale bars $=25 \mu \mathrm{m}$. Wild-type $(+/+), \mathrm{P}_{2} \mathrm{X}_{2}^{-l-}(-/-)$.

suring the incidence of centrally nucleated muscle fibers in adult (2-2.5 month old) wild-type and $\mathrm{P}_{2} \mathrm{X}_{2}{ }^{-1-}$ soleus muscle. The incidence of central nuclei in both wild-type and $\mathrm{P} 2 \mathrm{X}_{2}{ }^{-1-}$ muscle was low $(0.40 \pm 0.14 \%$ in wild-type soleus muscle; $0.42 \pm 0.06 \%$ in $\mathrm{P}_{2} \mathrm{X}_{2}{ }^{-1-}$ soleus muscle). However, muscle fibers in adult $\mathrm{P}_{2} \mathrm{X}_{2}{ }^{-1-}$ soleus muscle appeared smaller than wild-type soleus muscle fibers (Fig. 5a). Measurement of cross-sectional muscle fiber areas in the mid-belly region of adult wild-type and $\mathrm{P}_{2} \mathrm{X}_{2}{ }^{-1-}$ soleus muscles confirmed this finding. Muscle fiber cross-sectional areas in adult $\mathrm{P} 2 \mathrm{X}_{2}{ }^{-1-}\left(630 \pm 16 \mu \mathrm{m}^{2}\right)$ were significantly smaller $(P<0.038)$ than those in wild-type $\left(731 \pm 37 \mu \mathrm{m}^{2}\right)$ soleus muscle, indicating a reduced rate of muscle fiber growth in $\mathrm{P}_{2} \mathrm{X}_{2}{ }^{-1-}$ soleus muscle. There was no significant difference in the total number of muscle fibers present in wild-type $(859 \pm 45)$ compared with $\mathrm{P} 2 \mathrm{X}_{2}{ }^{-1-}(893 \pm 36)$ soleus muscle (Table 2).

\section{Changes in response to tetanic stimulation} in $\mathrm{P}_{2} \mathrm{X}_{2}^{-1-}$ soleus muscle

We assessed muscle function by comparing nerve-mediated twitch, muscle-mediated twitch and tetanic contractions in adult wild-type and $\mathrm{P} 2 \mathrm{X}_{2}{ }^{-1-}$ soleus muscles (Fig. $5 b$, Table 2). We found no difference between the forces developed by stimulating the muscle directly or indirectly by stimulation of the nerve, suggesting the absence of muscle denervation in either wild-type or $\mathrm{P}_{2} \mathrm{X}_{2}{ }^{-1-}$ adult soleus muscle. We assessed NMJ function further by investigating sensitivity to the AChR-specific antagonist, tubocurarine. While we were unable to demonstrate any significant difference between the $\mathrm{IC}_{50}$ values measured in $\mathrm{P}_{2 \mathrm{X}_{2}}{ }^{-1-}\left(\mathrm{IC}_{50}=5.76 \pm 0.14 \mu \mathrm{M}\right)$ and wild-type $\left(\mathrm{IC}_{50}=\right.$ $5.89 \pm 0.08 \mu \mathrm{M})$ soleus muscle, the results did suggest an increase in AChR reserve at $\mathrm{P} 2 \mathrm{X}_{2}{ }^{-1-} \mathrm{NMJs}$ (as shown by the increase in the concentration of tubocurarine required to inhibit muscle contraction on indirect nerve stimulation) (Fig. 5b).

No statistically significant differences could be detected between the force developed by single twitch contractions (generated by direct muscle stimulation) in wildtype and $\mathrm{P}_{2} \mathrm{X}_{2}{ }^{-1-}$ soleus muscles (Table 2). However, comparison of twitch contraction times demonstrated significantly $(P<0.0001)$ shorter times to peak contraction in $\mathrm{P}_{2 \mathrm{X}_{2}}{ }^{-1-}(86.69 \pm 1.53 \mathrm{~ms})$ as compared with wild-type $(97.38 \pm 1.57 \mathrm{~ms})$ soleus muscle suggesting the presence of a higher number of fast type fibers in $\mathrm{P} 2 \mathrm{X}_{2}{ }^{-1-}$ muscle (Fig. 5c). Furthermore, the force developed during tetanic stimulation was significantly $(P=0.043)$ reduced in soleus muscle from adult $P 2 X_{2}{ }^{-1-}\left(6.8 \pm 0.8 \mathrm{~g}, 584 \pm 10 \mathrm{~g} / \mathrm{cm}^{2}\right.$ of muscle) as compared with wild-type control (9.7 $\pm 1.4 \mathrm{~g}$, $1115 \pm 135 \mathrm{~g} / \mathrm{cm}^{2}$ of muscle) soleus muscle (Table 2 ).

Fast (type II) muscle fibers in wild-type and $\mathrm{P}_{2} \mathrm{X}_{2}{ }^{-I-}$ soleus muscle

Immunostaining of wild-type and $\mathrm{P}_{2} \mathrm{X}_{2}{ }^{-1-}$ soleus muscle with antibodies specific to fast skeletal muscle myosin demonstrated the presence of fast (green) and slow (black) fibers (Fig. 6a). Consistent with the findings of Kugelberg (1976), both wild-type and $\mathrm{P}_{2} \mathrm{X}_{2}{ }^{-1-}$ soleus muscle consisted predominantly of type II fibers (green) at P7, but showed an increase in the proportion of type I fibers (black) with age (Fig. 6a). However, by P14 the proportion of type II fibers (determined by immunostaining) appeared to be greater in $\mathrm{P} 2 \mathrm{X}_{2}{ }^{-1-}$ soleus muscle compared with age-matched wild-type controls (Fig. 6a). Demonstration of myofibrillar ATPase gave a similar pattern of expression with an increase in the expression of fast fibers (black) relative to slow fibers (white) (Fig. 6b). Quantitative

Table 1. Channel properties of AChRs expressed in wild-type $\left(\mathrm{P} 2 \mathrm{X}_{2}{ }^{+/+}\right)$and $\mathrm{P} 2 \mathrm{X}_{2}{ }^{-l-}$ muscle fibers

\begin{tabular}{|c|c|c|}
\hline Muscle & Mean open times (ms) & Conductance (pS) \\
\hline Adult $\mathrm{P}_{2} \mathrm{X}_{2}{ }^{+/+}(n=7)$ & $0.46 \pm 0.05$ & $45.6 \pm 2.0$ \\
\hline Adult $\mathrm{P} 2 \mathrm{X}_{2}{ }^{-1-}(n=7)$ & $0.63 \pm 0.05$ & $40.2 \pm 3.0$ \\
\hline Day $5 \mathrm{P}_{2} \mathrm{X}_{2}^{+/+}(n=6)$ & $4.80 \pm 1.20$ & $36.6 \pm 1.6$ \\
\hline
\end{tabular}


a
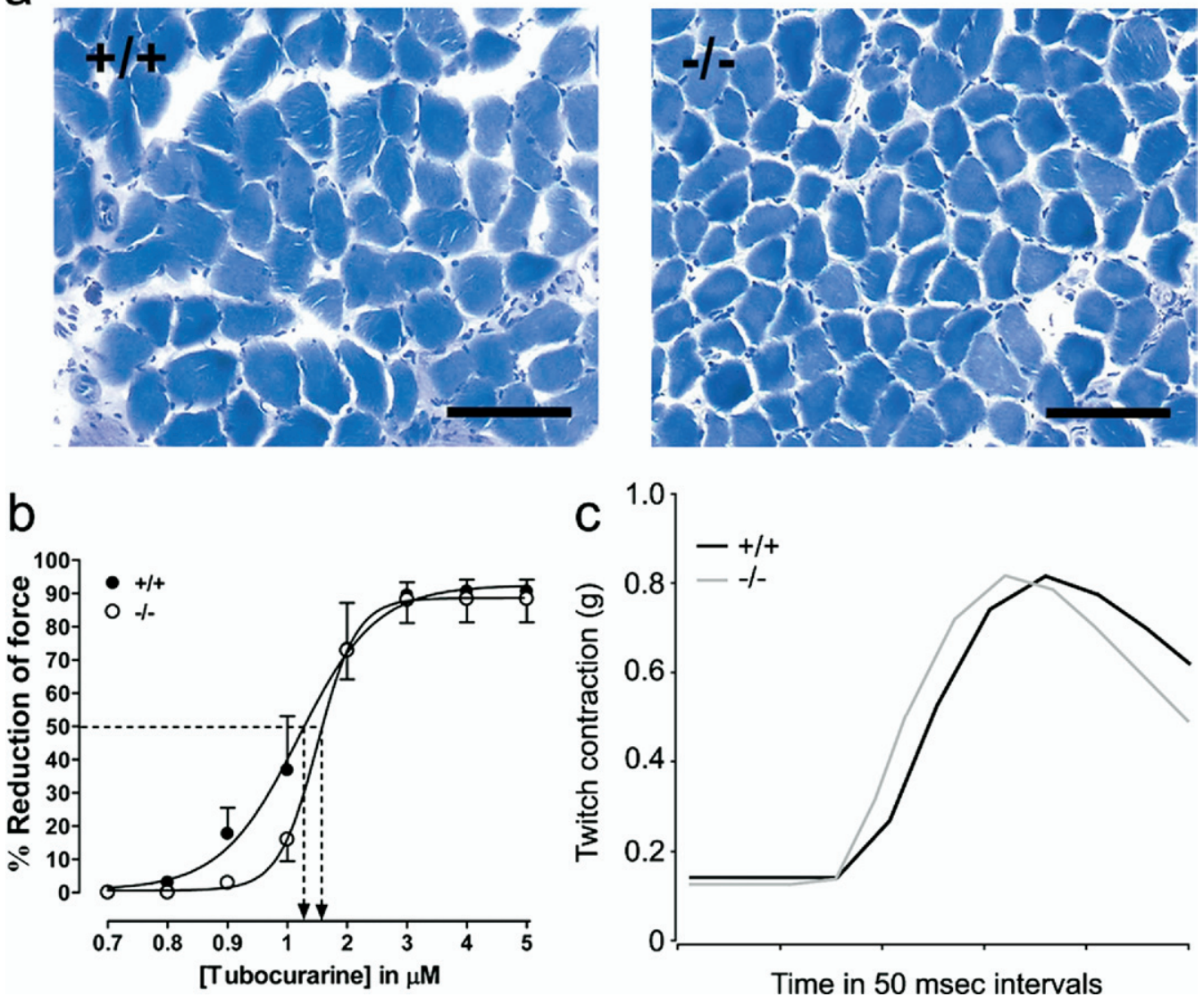

Fig. 5. Muscle fiber atrophy and changes in response to tetanic stimulation in soleus muscle from $P 2 X_{2}^{-1-}$ mice. (a) Wild-type and $P 2 X_{2}{ }^{-1-}$ adult soleus muscle stained with Toluidine Blue. While there was no evidence of muscle necrosis or regeneration of muscle fibers in adult P2X ${ }_{2}{ }^{-1-}$ soleus muscle, there was evidence of muscle fiber atrophy. Scale bars $=100 \mu \mathrm{m}$. (b) Dose inhibition curve for tubocurarine in wild-type (filled circles) and $\mathrm{P} 2 \mathrm{X}_{2}{ }^{-1-}$ (open circles) adult soleus muscle on indirect nerve stimulation. (c) Representative examples of twitch contractions in wild-type (black line) and $\mathrm{P}_{2} \mathrm{X}_{2}{ }^{-1-}$ (gray line) soleus muscle on direct muscle stimulation, demonstrating a significantly shorter time to peak contraction in $\mathrm{P} 2 \mathrm{X}_{2}{ }^{-1-}$ soleus muscle. Wild-type $(+/+), \mathrm{P}_{2} \mathrm{X}_{2}^{-1-}(-1-)$.

analysis of muscle fiber type in adult muscle demonstrated the presence of a significantly higher $(P=0.016)$ proportion of fast muscle fibers in adult $\mathrm{P} 2 \mathrm{X}_{2}{ }^{-1-}$ compared with wildtype soleus muscle. Whereas $57.0 \pm 2.2 \%$ of adult wildtype soleus muscle fibers were type II, $71.8 \pm 4.0 \%$ of adult $\mathrm{P} 2 \mathrm{X}_{2}{ }^{-1-}$ soleus muscle fibers were fast fibers (Fig. $6 \mathrm{c})$. Thus, the developmental transition from fast to slow muscle fibers failed to fully occur in $\mathrm{P}_{2} \mathrm{X}_{2}{ }^{-1-}$ soleus muscle.

\section{DISCUSSION}

Although ATP is well recognized as an important neurotransmitter in the CNS and peripheral nervous system mediating fast synaptic signaling (see Burnstock, 2007), the role of purinergic signaling in the formation and maintenance of synapses has not been fully investigated. In this study $\mathrm{P} 2 \mathrm{X}_{2}$ receptor-deficient mice were used to demonstrate a role for ATP signaling in the formation of mature

Table 2. Structural and contractile properties of wild-type $\left(P 2 X_{2}{ }^{+l+}\right)$ and $P 2 X_{2}^{-l-}$ soleus muscle

\begin{tabular}{|c|c|c|c|}
\hline & Adult P2X ${ }_{2}^{+/+}$ & Adult P2X ${ }_{2}^{-\prime-}$ & $P$-value \\
\hline Total no. of fibers & $859 \pm 45(n=4)$ & $893 \pm 36(n=4)$ & NS \\
\hline Fiber cross-sectional area $\left(\mu^{2}\right)$ & $731 \pm 37(n=4)$ & $630 \pm 16(n=4)$ & $P<0.05$ \\
\hline Twitch tension $(\mathrm{g})$ & $0.82 \pm 0.11(n=10)$ & $0.72 \pm 0.05(n=12)$ & NS \\
\hline Corrected twitch tension $\left(\mathrm{g} / \mathrm{cm}^{2}\right)$ & $92.5 \pm 11.4(n=4)$ & $70.4 \pm 1.0(n=4)$ & NS \\
\hline Time to peak contraction (ms) & $97.38 \pm 1.57(n=10)$ & $86.69 \pm 1.53(n=12)$ & $P<0.0001$ \\
\hline Tetanic tension $(\mathrm{g})$ & $9.7 \pm 1.4(n=10)$ & $6.8 \pm 0.8(n=12)$ & $P<0.05$ \\
\hline Corrected tetanic tension $\left(\mathrm{g} / \mathrm{cm}^{2}\right)$ & $1115 \pm 135(n=4)$ & $584 \pm 10(n=4)$ & $P<0.05$ \\
\hline
\end{tabular}



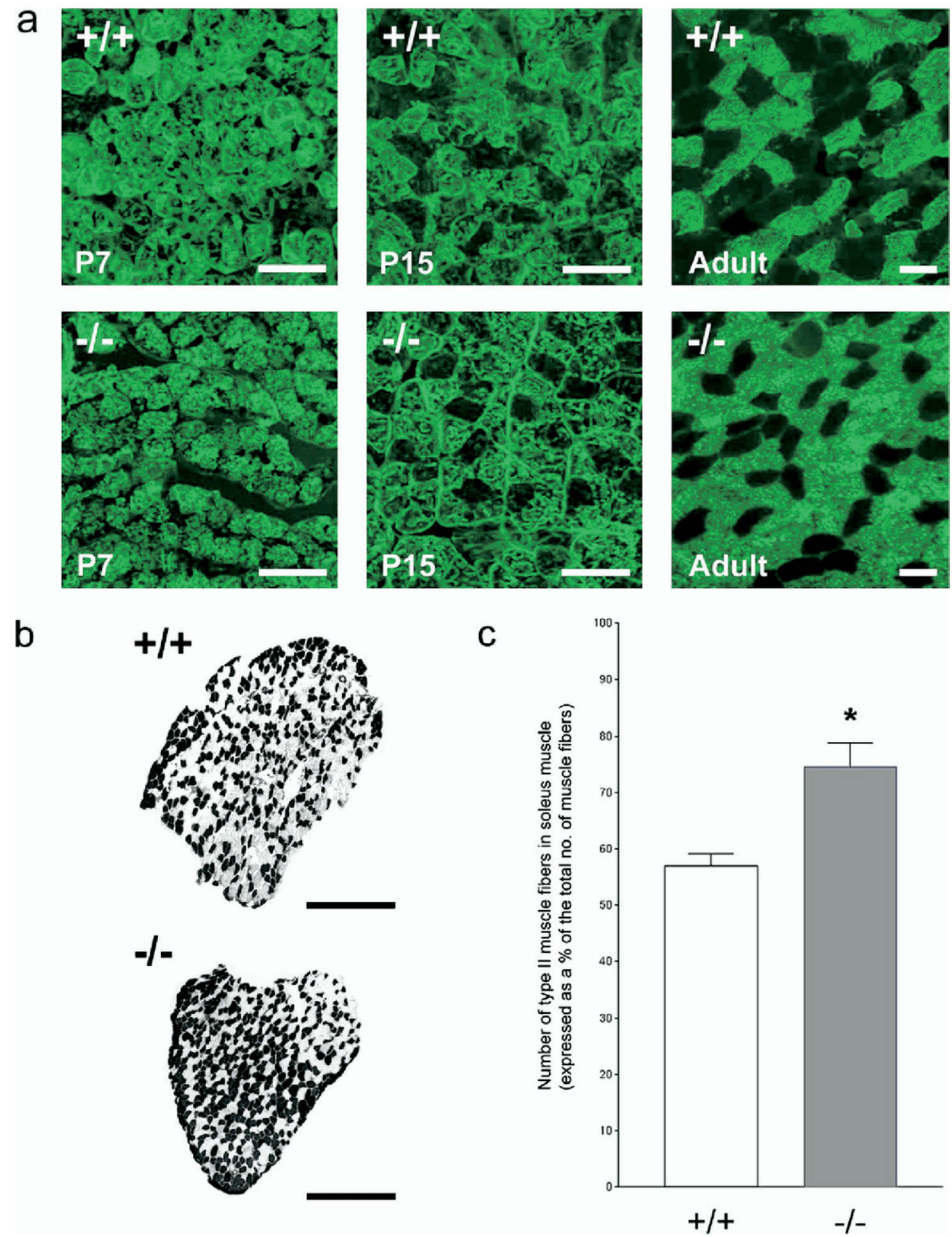

Fig. 6. Changes in muscle fiber type in $\mathrm{P}_{2} \mathrm{X}_{2}^{-1-}$ soleus muscle. (a) Immunostaining for fast type skeletal muscle myosin (green) in wild-type and $\mathrm{P} 2 \mathrm{X}_{2}{ }^{-1-} \mathrm{P} 7, \mathrm{P} 15$ and adult soleus muscle. Scale bars $=50 \mu \mathrm{m}$. (b) Standard ATPase enzyme histochemical staining (at pH 9.4) of whole sections of adult wild-type and $\mathrm{P}_{2} \mathrm{X}_{2}{ }^{-1-}$ soleus muscle to demonstrate the presence of type I (white) and type II (black) muscle fibers. Scale bars $=500 \mu \mathrm{m}$. (c) Histogram to show the numbers of fast (type II) muscle fibers in adult wild-type and $\mathrm{P}_{2} \mathrm{X}_{2}{ }^{-1-}$ soleus muscle (as determined by enzyme histochemistry) expressed as a \% of the total number of muscle fibers. The significant increase $(P<0.05)$ in the proportion of fast fibers in $\mathrm{P} 2 \mathrm{X}_{2}{ }^{-1-}$ as compared with wild-type adult soleus muscle is denoted by $\left(^{*}\right)$. Wild-type $(+/+), \mathrm{P}_{2} \mathrm{X}_{2}^{-1-}(-I-)$.

NMJs. Our results show that the normal expression of the $\mathrm{P} 2 \mathrm{X}_{2}$ receptor protein on developing skeletal muscle fibers is required for the formation and maintenance of mature NMJs and that absence of this receptor results in disorga- 
nized synapses. These defects in NMJ formation may result in less reliable neuromuscular transmission, as suggested by the incomplete transition from fast to slow muscle fiber type and decreased muscle fiber size.

Consistent with previous studies showing the expression of $\mathrm{P} 2 \mathrm{X}_{2}, \mathrm{P} 2 \mathrm{X}_{5}$ and $\mathrm{P} 2 \mathrm{X}_{6}$ receptors (Ryten et al., 2001, 2004), we demonstrated expression of $P 2 X_{2}$ receptors on developing wild-type mouse skeletal muscle using immunohistochemistry. This receptor was expressed on muscle fiber membranes in early postnatal skeletal muscle. We found no evidence of $\mathrm{P} 2 \mathrm{X}_{2}$ receptor expression in nerve fibers or surrounding Schwann cells, nor has such expression been reported in mammalian NMJs in the literature to date. However, functional P2X receptors have been demonstrated in peri-synaptic Schwann cells in frog NMJs, so the possibility that these receptors are present on Schwann cells in mammalian NMJs cannot be excluded (Robitaille, 1995). Nonetheless, these findings suggest that while the $\mathrm{P}_{2} \mathrm{X}_{2}$ receptor was not specifically expressed at mature muscle endplates, the observed changes in NMJ structure and skeletal muscle function in the $\mathrm{P} 2 \mathrm{X}_{2}{ }^{-1-}$ mouse were most likely to be due to the absence of $\mathrm{P} 2 \mathrm{X}_{2}$ receptor-mediated signaling on developing muscle cells.

The timing of $\mathrm{P} 2 \mathrm{X}_{2}$ receptor expression is consistent with the pattern of abnormalities observed in $\mathrm{P}_{2} \mathrm{X}_{2}{ }^{-1-}$ skeletal muscle. The $\mathrm{P} 2 \mathrm{X}_{2}$ receptor was not expressed in embryonic and adult skeletal muscle, but was present in early postnatal development. Therefore absence of this receptor would be expected to affect the later stages of muscle development. In keeping with this view, we found no change in muscle fiber number in $\mathrm{P}_{2} \mathrm{X}_{2}{ }^{-1-}$ soleus muscle, the total number of muscle fibers formed being dependent on myotube formation, a process which is completed by birth. Similarly, AChR clustering which rapidly follows myotube formation in the embryo (Sanes and Lichtman, 2001), occurred normally in $\mathrm{P}_{2} \mathrm{X}_{2}{ }^{-1-}$ skeletal muscle. However, abnormalities in NMJ maturation (including the formation of a complex pretzel-like shape from a simple oval cluster of AChRs and the formation of postsynaptic folds), muscle fiber typing and muscle fiber growth were all affected in skeletal muscle of $\mathrm{P} 2 \mathrm{X}_{2}{ }^{-1-}$ mice.

Abnormalities in $\mathrm{P}_{2} \mathrm{X}_{2}{ }^{-1-}$ skeletal muscle, including disorganized NMJs and an increase in fast muscle fibers, became apparent from P15. Staining for AChRs revealed the ragged appearance of many of the endplates and electron microscopy demonstrated reduced numbers and depth of post-synaptic folds. However, these differences between wild-type and $\mathrm{P} 2 \mathrm{X}_{2}{ }^{-1-} \mathrm{NMJs}$ became more significant in adult tissues.

This might suggest a role for $\mathrm{P} 2 \mathrm{X}_{2}$ receptor-mediated purinergic signaling in NMJ maintenance. While we did not detect $\mathrm{P}_{2} \mathrm{X}_{2}$ receptor expression in healthy adult skeletal muscle, this observation could be explained by the need for re-expression of this receptor on muscle injury (a frequent occurrence in the lifetime of animals). This interpretation of the findings is supported by recent studies demonstrating re-expression of the $\mathrm{P} 2 \mathrm{X}_{2}$ receptor in regener- ating skeletal muscle fibers in the mdx (mouse model) of muscular dystrophy (Ryten et al., 2004).

The most striking abnormalities in $\mathrm{P}_{2} \mathrm{X}_{2}{ }^{-1-}$ skeletal muscle were observed at NMJs. Adult $\mathrm{P}_{2} \mathrm{X}_{2}{ }^{-1-}$ NMJs consisted of significantly more AChR clusters/endplate spread over a wider area as compared with wild-type controls. There was mis-apposition between pre-synaptic nerve terminal specialization and post-synaptic muscle differentiation in $\mathrm{P}_{2} \mathrm{X}_{2}{ }^{-1-}$ NMJs. Most significantly there was a marked reduction in post-synaptic folding at $\mathrm{P} 2 \mathrm{X}_{2}{ }^{-1-}$ muscle endplates. The absence of any physiological data to suggest partial or complete muscle denervation suggests that the abnormalities in NMJ structure did not prevent neurotransmission. However, the reliability of neurotransmission may have been affected. While effective neurotransmission occurs (in embryonic life) without many of the pre- and post-synaptic specializations associated with mature NMJs, these specializations are required to ensure synapse reliability (Slater, 2003). Therefore the abnormalities in NMJ structure present in adult $\mathrm{P}_{2} \mathrm{X}_{2}{ }^{-1-}$ skeletal muscle might still be expected to result in abnormal function. Indeed the generalized atrophy of muscle fibers and increased percentage of fast type muscle fibers in adult $\mathrm{P}_{2} \mathrm{X}_{2}{ }^{-1-}$ soleus muscle is not only consistent, but suggestive of abnormal neuromuscular transmission. Whereas adult wild-type and $\mathrm{P} 2 \mathrm{X}_{2}{ }^{-1-}$ soleus muscle contained similar numbers of fibers, $\mathrm{P} 2 \mathrm{X}_{2}$ receptor-deficient muscle generated lower forces on tetanic stimulation. This difference could be explained by significant fiber atrophy in $\mathrm{P} 2 \mathrm{X}_{2}{ }^{-1-}$ muscle secondary to reduced activity. Reliable neurotransmission is also important in directing muscle fiber typing (Carrasco and English, 2003). The transition from fast to slow type muscle fibers is induced by increased muscle activation during development (Kugelberg, 1976). Therefore, the failure of complete fiber type transition (fast to slow) in $\mathrm{P}_{2} \mathrm{X}_{2}{ }^{-1-}$ soleus muscle strongly suggests that the abnormal NMJs of $\mathrm{P} 2 \mathrm{X}_{2}{ }^{-1-}$ mice are unable to effectively transmit this increased activity. Thus, the defects in NMJ structure observed at EM and by confocal microscopy are likely to be of functional significance.

The abnormalities in NMJ structure, muscle fiber type and size demonstrated in $\mathrm{P}_{2} \mathrm{X}_{2}{ }^{-1-}$ muscle could be explained by a single role for $\mathrm{P} 2 \mathrm{X}_{2}$ receptor-dependent signaling in the development and maintenance of NMJs. Other explanations might include the possibility of a more general role for $\mathrm{P}_{2} \mathrm{X}_{2}$ receptors in muscle activation, suggesting that changes in NMJ structure are secondary. However, since the most pronounced changes in muscle were observed at the NMJs, we feel that the primary effect of $\mathrm{P} 2 \mathrm{X}_{2}$ receptor-dependent signaling is likely to be on NMJ morphology. Unlike $\mathrm{P}_{2} \mathrm{Y}_{1}$ receptor activation, which increases the expression of AChR protein (Choi et al., 2001; Ling et al., 2004), we were unable to demonstrate a significant change in the total expression of AChRs on soleus muscle in $\mathrm{P}_{2} \mathrm{X}_{2}{ }^{-1-}$ mice. We found no significant difference in the total area or density of AChR staining at endplates, and although there was a mild reduction in tubocurarine sensitivity in $\mathrm{P}_{2} \mathrm{X}_{2}{ }^{-1-}$ muscle, we found no significant differences in the $\mathrm{IC}_{50}$ values in wild-type and 
$\mathrm{P} 2 \mathrm{X}_{2}{ }^{-1-}$ soleus muscle. Nor did we detect any significant differences in the AChR subtypes expressed at wild-type as compared with $\mathrm{P} 2 \mathrm{X}_{2}{ }^{-1-}$ endplates (using single channel recording or immunohistochemistry). Although these latter experiments were conducted on the flexor digitorum brevis muscles, where NMJ structure was not investigated, previous studies suggest that $\mathrm{P} 2 \mathrm{X}_{2}$ receptor expression is part of the developmental program of all muscle fibers and that extrapolating findings to the soleus muscle may be valid (Ryten et al., 2001, 2004).

Thus, $\mathrm{P}_{2} \mathrm{X}_{2}$ receptor-dependent signaling appears to play a specific role in directing some features of endplate morphology. This function is consistent with the well-recognized importance of innervation in NMJ formation, and the fact that while the $\mathrm{P} 2 \mathrm{X}_{2}$ receptor may be expressed across the muscle membrane, the most significant release of ATP is likely to be at the motor nerve terminal where this transmitter is co-released with ACh. Furthermore, the specific properties of the $\mathrm{P} 2 \mathrm{X}_{2}$ receptor make it particularly well-suited to a role in directing $A C h R$ distribution. The singular ability of this receptor to interact with nicotinic AChRs in a density-dependent manner to produce crossinhibition of channel opening (Nakazawa, 1994; Searl et al., 1998; Zhou and Galligan, 1998; Khakh et al., 2000) suggests a mechanism by which $\mathrm{P} 2 \mathrm{X}_{2}$ receptor activation could mediate localized effects on AChR expression. Previous studies conducted by O'Malley et al. (1997), demonstrating that ATP can stabilize AChRs on cultured myotubes to increase receptor half-life, support this theory. Certainly a role for purinergic signaling in ensuring AChR stability could explain the timing of $\mathrm{P}_{2} \mathrm{X}_{2}$ receptor expression in early postnatal life, the need for re-expression on muscle regeneration and the variability in NMJ structure seen in the $\mathrm{P}_{2} \mathrm{X}_{2}^{-1-}$ mice.

\section{CONCLUSION}

In summary, we demonstrate that absence of the $\mathrm{P} 2 \mathrm{X}_{2}$ receptor on skeletal muscle results in significant abnormalities in muscle structure and function. These effects can be explained most simply by proposing a role for the $\mathrm{P} 2 \mathrm{X}_{2}$ receptor in the normal development of the NMJ. It is becoming increasingly clear that the development and maintenance of synapses is a complex process requiring a balance between stabilizing and de-stabilizing factors. A number of other factors have been shown to influence the latter steps of NMJ formation, including laminin $\alpha 4$ expression (Patton et al., 2001) and cholinergic neurotransmission (Misgeld et al., 2002, 2005; Brandon et al., 2003). However, much less is known about the maturation and maintenance of synapses than about the initial steps in their formation (Sanes and Lichtman, 1999). Thus, the coordinated action of a number of signaling systems, including the stabilizing effects of $\mathrm{P}_{2} \mathrm{X}_{2}$ receptor-mediated purinergic signaling, is likely to be necessary to ensure synapse plasticity not only at the NMJ, but also in the CNS where the $\mathrm{P} 2 \mathrm{X}_{2}$ receptor is also strongly expressed.

\section{REFERENCES}

Barajas-López C, Espinosa-Luna R, Zhu Y (1998) Functional interactions between nicotinic and P2X channels in short-term cultures of guinea pig submucosal neurons. J Physiol (Lond) 513:671-683.

Bo X, Schoepfer R, Burnstock G (2000) Molecular cloning and characterization of anovel ATP P2X receptor subtype from embryonic chick skeletal muscle. J Biol Chem 275:14401-14407.

Brandon EP, Lin W, D'Amour KA, Pizzo DP, Dominguez B, Sugiura Y, Thode S, Ko CP, Thal LJ, Gage FH, Lee KF (2003) Aberrant patterning of neuromuscular synapses in choline acetyltransferase-deficient mice. J Neurosci 23:539-549.

Burnstock G (2007) Physiology and pathophysiology of purinergic neurotransmission. Physiol Rev 87:659-797.

Carrasco DI, English AW (2003) Neurotrophin 4/5 is required for the normal development of the slow muscle fibre phenotype in the rat soleus. J Exp Biol 206:2191-2200.

Cheung KK, Ryten M, Burnstock G (2003) Abundant and dynamic expression of $\mathrm{G}$ protein-coupled $\mathrm{P} 2 \mathrm{Y}$ receptors in mammalian development. Dev Dyn 228:254-266.

Choi RC, Man ML, Ling KK, Ip NY, Simon J, Barnard EA, Tsim KW (2001) Expression of the P2Y 1 nucleotide receptor in chick muscle: its functional role in the regulation of acetylcholinesterase and acetylcholine receptor. J Neurosci 21:9224-9234.

Cockayne DA, Dunn PM, Zhong Y, Hamilton SG, Cain GR, Knight GE, Ruan H-Z, Ping $Y$, Nunn P, Bei M, McMahon SB, Burnstock G, Ford APDW (2005) P2 $X_{2}$ knockout mice and $P 2 X_{2} / P 2 X_{3}$ double knockout mice reveal a role for the $\mathrm{P} 2 \mathrm{X}_{2}$ receptor subunit in mediating multiple sensory effects of ATP. J Physiol 567:621-639.

Dubowitz V (1985) Muscle biopsy: a practical approach, 2nd ed, pp 19-40. London: Bailliere Tindall.

Heilbronn E, Eriksson H (1998) Second messengers mobilized by ATP and $\mathrm{ACh}$ in the myotube/muscle fiber. In: Neuromuscular junction (Sellin LC, Libelius R, Thesleff S, eds), pp 395-404. Amsterdam, The Netherlands: Elsevier Science Publishers.

Henning RH (1997) Purinoceptors in neuromuscular transmission. Pharmacol Ther 74:115-128.

Henning RH, Nelemans A, van den Akker J, den Hertog A (1992) The nucleotide receptors on mouse $\mathrm{C} 2 \mathrm{C} 12$ myotubes. $\mathrm{Br} \mathrm{J}$ Pharmacol 106:853-858.

Hume RI, Thomas SA (1988) Multiple actions of adenosine 5'-triphosphate on chick skeletal muscle. J Physiol 406:503-524.

Jiang T, Yeung D, Lien CF, Gorecki DC (2005) Localized expression of specific P2X receptors in dystrophin-deficient DMD and $\mathrm{mdx}$ muscle. Neuromuscul Disord 15:225-236.

Khakh BS, Zhou X, Sydes J, Galligan JJ, Lester HA (2000) Statedependent cross-inhibition between transmitter-gated cation channels. Nature 406:405-410.

Kolb HA, Wakelam MJ (1983) Transmitter-like action of ATP on patched membranes of cultured myoblasts and myotubes. Nature 303:621-623.

Kugelberg $E$ (1976) Adaptive transformation of rat soleus motor units during growth. J Neurol Sci 27:269-289.

Ling KK, Siow NL, Choi RC, Ting AK, Kong LW, Tsim KW (2004) ATP potentiates agrin-induced AChR aggregation in cultured myotubes: activation of RhoA in $\mathrm{P}_{2} \mathrm{Y}_{1}$ nucleotide receptor signaling at vertebrate neuromuscular junctions. J Biol Chem 279:31081-31088.

Meyer MP, Clarke JD, Patel K, Townsend-Nicholson A, Burnstock G (1999a) Selective expression of purinoceptor $\mathrm{cP} \mathrm{Y}_{1}$ suggests a role for nucleotide signaling in development of the chick embryo. Dev Dyn 214:152-158.

Meyer MP, Gröschel-Stewart U, Robson T, Burnstock G (1999b) Expression of two ATP-gated ion channels, $\mathrm{P} 2 \mathrm{X}_{5}$ and $\mathrm{P} 2 \mathrm{X}_{6}$, in developing chick skeletal muscle. Dev Dyn 216:442-449.

Misgeld T, Kummer TT, Lichtman JW, Sanes JR (2005) Agrin promotes synaptic differentiation by counteracting an inhibitory 
effect of neurotransmitter. Proc Natl Acad Sci U S A 102: 11088-11093.

Misgeld T, Burgess RW, Lewis RM, Cunningham JM, Lichtman JW, Sanes JR (2002) Roles of neurotransmitter in synapse formation: development of neuromuscular junctions lacking choline acetyltransferase. Neuron 14:635-648.

Missias AC, Mudd J, Cunningham JM, Steinbach JH, Merlie JP, Sanes JR (1997) Deficient development and maintenance of postsynaptic specializations in mutant mice lacking an 'adult' acetylcholine receptor subunit. Development 124:5075-5086.

Nakazawa K (1994) ATP activated current and its interaction with acetylcholine activated current in rat sympathetic neurons. J Neurosci 14:740-750.

O'Malley JP, Moore CT, Salpeter MM (1997) Stabilization of acetylcholine receptors by exogenous ATP and its reversal by cAMP and calcium. J Cell Biol 138:159-165.

Patton BL, Cunningham JM, Thyboll J, Kortesmaa J, Westerblad H, Edstrom L, Tryggvason K, Sanes JR (2001) Properly formed but improperly localized synaptic specializations in the absence of laminin $\alpha 4$. Nat Neurosci 4:597-604.

Ralevic V, Burnstock G (1998) Receptors for purines and pyrimidines. Pharmacol Rev 50:413-492.

Redman RS, Silinsky EM (1994) ATP released together with acetylcholine as the mediator of neuromuscular depression at frog motor nerve endings. J Physiol 477:117-127.

Robitaille R (1995) Purinergic receptors and their activation by endogenous purines at perisynaptic glial cells of the frog neuromuscular junction. J Neurosci 15:7121-7131.

Ruppelt A, Ma W, Borchardt K, Silberberg SD, Soto F (2001) Genomic structure, developmental distribution and functional properties of the chicken $\mathrm{P}_{2} \mathrm{X}_{5}$ receptor. J Neurochem 77: $1256-1265$.
Ryten M, Hoebertz A, Burnstock G (2001) Sequential expression of three receptor subtypes for extracellular ATP in developing rat skeletal muscle. Dev Dyn 221:331-341.

Ryten M, Dunn PM, Neary JT, Burnstock G (2002) ATP regulates the differentiation of mammalian skeletal muscle by activation of a P2X ${ }_{5}$ receptor on satellite cells. J Cell Biol 158:345-355.

Ryten M, Yang SY, Dunn PM, Goldspink G, Burnstock G (2004) Purinoceptor expression in regenerating skeletal muscle in the $\mathrm{mdx}$ mouse model of muscular dystrophy and in satellite cell cultures. FASEB J 18:1404-1406.

Sanes JR, Lichtman JW (1999) Development of the vertebrate neuromuscular junction. Annu Rev Neurosci 22:389-442.

Sanes JR, Lichtman JW (2001) Induction, assembly, maturation and maintenance of a postsynaptic apparatus. Nat Rev Neurosci 2:791-805.

Searl TJ, Redman RS, Silinsky EM (1998) Mutual occlusion of P2X ATP receptors and nicotinic receptors on sympathetic neurons of the guinea-pig. J Physiol (Lond) 510:783-791.

Silinsky EM, Redman RS (1996) Synchronous release of ATP and neurotransmitter within milliseconds of a motor nerve impulse in the frog. J Physiol 492:815-822.

Slater CR (2003) Structural determinants of the reliability of synaptic transmission at the vertebrate neuromuscular junction. J Neurocytol 32:505-522.

Thomas SA, Zawisa MJ, Lin X, Hume RI (1991) A receptor that is highly specific for extracellular ATP in developing chick skeletal muscle in vitro. $\mathrm{Br} \mathrm{J}$ Pharmacol 1034:1963-1969.

Wells DG, Zawisa MJ, Hume RI (1995) Changes in responsiveness to extracellular ATP in chick skeletal muscle during development and upon denervation. Dev Biol 172:585-590.

Zhou X, Galligan JJ (1998) Non-additive interaction between nicotinic cholinergic and $\mathrm{P} 2 \mathrm{X}$ purine receptors in guinea-pig enteric neurons in culture. J Physiol 513:685-697. 